sciendo Zagreb International Review of Economics \& Business, Vol. 24, Special Conference Issue, pp. 63-75, 2021 (C) 2020 Faculty of Economics and Business, University of Zagreb and De Gruyter Open

All rights reserved. Printed in Croatia

ISSN 1331-5609; UDC: $33+65$

DOI: 10.2478 /zireb-2021-0020

CONFERENCE PAPER

\title{
Are People Willing to Voluntarily Contribute to Public Goods? The Results from the Behavioral Game Experiment.
}

\author{
Eva Sirakovová* \\ Anetta Čaplánová*
}

Abstract: In the paper, we discuss the possibilities of alternative provision of public goods using the
individual voluntary contributions. We use the data from the behavioral public goods game
based on the model of voluntary contribution mechanism. We examine how people's deci-
sions about voluntary contributions to public goods change when the environment changes.
The participants of the game were divided into small (5 persons) and large (10 persons)
groups. During the game participants were asked to invest experimental money to different
types of accounts, i.e. private account, Group account 1 and Group account 2 . Using the
game, we also examine the impact of a provision point on voluntary contributions. Based
on the analysis of the data from this behavioral game, we found that the provision point is
effective only if the participants are members of a small group. When the participants were
members of both a small group and of a large group the provision point was not effective.
When the income of participants was considered, we found that participants with higher ex-
perimental income were less willing to voluntarily contribute to financing of a public good.

Keywords: behavioral economics; voluntary contribution mechanism; public goods game; online experiment; provision point; small and large groups

JEL Classification: $\mathrm{H} 41, \mathrm{H} 42, \mathrm{C} 92$

\section{Introduction}

The increasing popularity of behavioral and experimental economics has brought a shift away from mainstream economics in many areas. The concept of public goods is not an exception. Numerous economic experiments in this area proved, that under certain conditions, people are willing to contribute voluntarily to the financing of

\footnotetext{
* Eva Sirakovová and Anetta Čaplánová are at University of Economics in Bratislava, Bratislava, Slovakia
} 
public goods, and thus, there are people who do not become free riders, even if they have conditions to do so. The standard model assumes, that rational subjects will not be willing to contribute to public goods financing and they become free riders. In our research, based on the data obtained from the behavioral game experiment, we examine whether subjects behave rationally, i.e., if they free ride. When people are willing to contribute to public goods financing, they behave irrationally contrary to the standard model, and the standard theory has only limited validity.

In this paper, we consider alternative mechanisms of providing public goods and we focus on the voluntary contribution mechanism. We examine this mechanism using an online behavioral game, which we have developed. We used the data collected in this behavioral game to study, how behavior of people changes when the game setting changes. In particular, we focus on how people deciding to become a free rider or not. The ask how an individual's decision to contribute to public goods is affected by such factors as, e.g., individual income, the size of the group or the provision point.

The paper is structured as follows. In the next section, we review relevant literature, then, we describe the methodology and present the results, finally, we conclude the paper with the summary and concluding remarks.

\section{Literature review}

One of the alternative mechanisms for the provision of public goods is their private provision. Olson (1965) describes basic principles of group behavior, and the influence of a group size on people's behavioral changes. He concludes that economic incentives like money, are not the only important incentive, but people are also affected by the desire to gain prestige, respect, friendship. Also, social and psychological aspects have great influence on people's behavior and decisions in groups.

In other studies, focusing on private provision of public goods, (e.g. Bergstrom et al. (1986), Corners and Sandler (1984,1985), Andreoni (1988)) the model of private provision of public goods is based on the so-called public goods game (or a voluntary contribution mechanism). In the public goods game, the participants usually invest experimental money into two types of accounts, a private account and a group account, where the group account represents the public good. Robeldo (2000) describes three main assumptions of public goods game: a) the participants of the game (individuals) are interested in the overall supply of the public good and their individual consumption of the private good, b) the total supply of public goods is given by the sum of the contributions of individuals (i.e., the contribution of different individuals are perfect substitutes), c) the contributions of others are independent of contributions of an individual (the Nash equilibrium condition).

One of the first experiments with the public goods game is described in Marwell and Ames $(1979,1980)$. They experimentally tested the validity of the theory of pure 
public goods and the role of the free rider problem. Their study is based on the hypothesis that large groups would provide fewer public goods than small groups and assumed that a larger proportion of free riders should be in larger groups than in smaller groups. There were four members in the small group and 80 members in the large group. However, no subject was actually a member of a group of 80 persons. The authors just tell them that there were any number of members in their group and have them make their investment decisions in terms of this assumption. Perhaps, the most important finding of this study is that the actual results did not correspond to the hypothesis. They found that in a small group (i.e., group with four members) approximately 57 percent of experimental money went to the group account.

The free rider hypothesis has long been an important part of public goods game experiments. Although the number of free riders varies across experiments, there are three common observations, which occur repeatedly. First, there is no significant incidence of free riders in single-shot games. Second, if subjects play a repeated game, the number of free riders increases with each repetition. This phenomenon was observed, when subjects know the duration of the game (Isaac, Walker, Thomas, 1984), but also when they do not know it (Isaac, McCue and Plott, 1985). Third, the number of free riders often increases after multiple rounds, but the so-called "pure free riding", i.e., the situation, in which no one contributes to the public good, occurs only rarely.

In their experimental study of individual contributions in the voluntary contribution mechanism game with different levels of income (wealth) Backley and Croson (2006) show that these are inconsistent with any self-interest, altruism, or inequality models. Low-income participants contributed about the same absolute amount (i.e., higher percentage of their income) to the provision of public goods than higher-income individuals. Also, Hofmeyr et al. (2007) did not find statistically significant differences between nominal contributions of high-income and low-income individuals to the public good.

One of the popular modifications of the voluntary contribution mechanism is the introduction of the provision point (or a threshold). The provision point is the minimum amount that must be invested in a group account for the public good to be provided. In a series of laboratory and field experiments, Rondeau and List (2008) observed a very strong impact of the provision point on behavior of individuals. They found that the participants of the experiment contributed significantly more to the group account, when the provision point was added. Bagnoli and Lipman (1992) or McBride (2004) observed the convergence of individual contributions towards the size of the provision point.

Reciprocity and commitment also have been shown to have a significant impact on decisions of individuals regarding their contribution to public goods. These factors have also been studied experimentally. Kurzban et al. (2001) confirmed that individuals were willing to contribute to financing of public goods at or slightly above 
the level of the lowest contributor in the group. The findings of this research also showed that individuals were averse to inequality, which significantly affected their contribution to public goods.

Another experimental study (Croson et al. 2005) was consistent with findings of other experiments focusing on the reciprocity effect in the voluntary contribution mechanism. It showed that the experimental subjects tried to compare their contribution with that of other members of the group, and there was a convergence of contributions towards the amount of the minimum contribution of the members of the group. The analysis of individual behavior in groups documents that social comparison is an important factor for motivating people to contribute voluntary to financing of public goods.

\section{Methodology}

The online behavioral game we use in our research was designed so as it has one introductory round consisting of a knowledge quiz used to allocate experimental money and four rounds of the game, where participants played an online public goods game. In each round, detailed instructions were provided to participants, and they also included an illustrative example of how player's payoffs will be calculated. This behavioral game was run twice with a different set of subjects. The participants of the first experiment were recruited using an online form made available on Facebook. Only those participants were financially rewarded, who were members of the winning group. This group consisted of 5 people (i.e., one small group) and their cumulative payoff for the entire duration of the experiment was the highest. The winners were paid out $0,3 €$ for 1 experimental money unit.

In the second experiment, the participants were students of the University of Economics in Bratislava. They were motivated to participate in the game with additional points for activity in a course. Thus, every student was rewarded for participation in the experiment and members of the winning group earned an additional point. Thus, each student received 2 additional points and members of the winning group earned an additional extra point.

We used the knowledge quiz to differentiate participants in terms of their experimental income, but also a very important factor is that the participants perceived the experimental money as their earnings. In the quiz, the participants had the opportunity to earn experimental money, which in the game they invested to different accounts. The table 1 shows the exchange ratio between the correct answers in the quiz and the amount of experimental money earned. 
Table 1: The exchange ratio between correct answers and the amount of experimental money earned

\begin{tabular}{|l|c|c|c|c|}
\hline The number of correct answers & $0-5$ & $6-10$ & $11-15$ & $16-20$ \\
\hline The amount of experimental money earned & 10 & 20 & 30 & 40 \\
\hline
\end{tabular}

Source: Author's specification

After the quiz, participants learnt how much experimental money they earned. In the first treatment, the participants were randomly divided into small groups (of 5 people). Each participant had to make a decision how much of their experimental money they will invest to each account - a Private account (P) and a Group account (G). The private account is only an individual account and the payoff from this account equals to the investment in it. In the Group account 1 (G1) 5 people contributed (1 small group). Investments to this account were multiplied by 1.2 and then, they were distributed among participants, regardless of whether or how much they contributed to this account. Thus, an individual payoff consists of two partial payoffs, i.e., the payoff from the private account and from the group account. In the second treatment, we added the provision point. This means that the revenue from the group account was conditioned by collecting minimum 20 experimental money to this account. All other characteristics of the game remained unchanged.

In the third treatment, we added a new group account, i.e., Group account 2 (G2). Investments to Group account 2 were multiplied by 1.3 . No provision point was added in this treatment. In this treatment, one participant was a member of two groups - a small and a large group. A large group consisted of 10 participants (i.e., one large group $=$ two small groups).

In the last treatment, we used the provision points for both group accounts. The threshold for Group account 1 was 20 experimental money units, the threshold for Group account 2 was 30 experimental money units. In the first experiment 40 subjects participated (i.e., 8 small groups of 5 people and 4 large groups of 10 people). In the second experiment, there were 60 subjects (i.e., there were 12 small groups and 6 large groups). At the end of the game, the participants completed the demographic questionnaire in which we collected information on their gender, age and education. The survey was anonymous, and the participants signed an informed consent clause.

Then, we analyzed the data. First, we used the Wilcoxon signed-rank test. It is a non-parametric test that is often used for the analysis of experimental data. The test monitors the sums of positive, resp. negative numbers of the order of differences and thus compares the differences of values between the first and repeated measurements. Second, we ran multiple linear regression. In our model, the dependent variable were contributions to the Group account 1. Independent variables were dummy variables that were created to estimate the impact of different treatment modifications, age of the subjects, if they had university education and the gender on voluntary contribu- 
tions to public goods. In our model, experimental income was also an independent variable, since we focused on different income-level groups.

\section{Results}

In the following table, we present the average contributions in each treatment for the both experiments. The data of average investments are given as a percentage of experimental income, as the participants in both experiments were differentiated by their income.

Table 2: Average contributions for each treatment to all accounts in both experiments (percentage of experimental income)

\begin{tabular}{|c|c|c|c|c|c|c|c|c|c|c|c|c|}
\hline \multirow[t]{2}{*}{$\mathrm{E}$} & \multirow{2}{*}{$\begin{array}{l}\text { Treatment/ } \\
\text { Experimental } \\
\text { income }\end{array}$} & \multicolumn{2}{|c|}{ First } & \multicolumn{2}{|c|}{ Second } & \multicolumn{3}{|c|}{ Third } & \multicolumn{3}{|c|}{ Fourth } & \multirow{2}{*}{$\begin{array}{l}\text { Number } \\
\text { of } \\
\text { subjects }\end{array}$} \\
\hline & & $\mathrm{P}$ & G1 & $\mathrm{P}$ & G1 & $\mathrm{P}$ & G1 & $\mathrm{G} 2$ & $P$ & G1 & G2 & \\
\hline \multirow{4}{*}{ 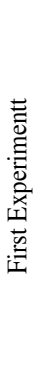 } & $\begin{array}{l}\text { Low experimental } \\
\text { income (10) }\end{array}$ & $57.0 \%$ & $43.0 \%$ & $49.0 \%$ & $51.0 \%$ & $49.0 \%$ & $34.0 \%$ & $17.0 \%$ & $54.9 \%$ & $34.0 \%$ & $12.0 \%$ & 9 \\
\hline & $\begin{array}{l}\text { Middle-low } \\
\text { experimental } \\
\text { income }(20)\end{array}$ & $65.0 \%$ & $35.0 \%$ & $55.0 \%$ & $45.0 \%$ & $75.0 \%$ & $15.0 \%$ & $10.0 \%$ & $60.0 \%$ & $20.0 \%$ & $20.0 \%$ & 6 \\
\hline & $\begin{array}{l}\text { Middle-high } \\
\text { experimental } \\
\text { income }(30)\end{array}$ & $51.6 \%$ & $37.4 \%$ & $58.5 \%$ & $25.0 \%$ & $61.5 \%$ & $15.7 \%$ & $22.9 \%$ & $51.5 \%$ & $27.8 \%$ & $20.7 \%$ & 12 \\
\hline & $\begin{array}{l}\text { High experimental } \\
\text { income }(40)\end{array}$ & $47.7 \%$ & $52.3 \%$ & $53.4 \%$ & $75.0 \%$ & $55.3 \%$ & $13.9 \%$ & $24.5 \%$ & $67.5 \%$ & $11.1 \%$ & $15.2 \%$ & 13 \\
\hline \multirow{4}{*}{ 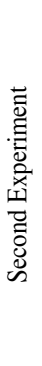 } & $\begin{array}{l}\text { Low experimental } \\
\text { income (10) }\end{array}$ & $50.0 \%$ & $37.5 \%$ & $55.0 \%$ & $45.0 \%$ & $41.3 \%$ & $32.5 \%$ & $26.3 \%$ & $43.8 \%$ & $27.5 \%$ & $30.0 \%$ & 16 \\
\hline & $\begin{array}{l}\text { Middle-low } \\
\text { experimental } \\
\text { income }(20)\end{array}$ & $60.0 \%$ & $40.0 \%$ & $25.0 \%$ & $75.0 \%$ & $25.0 \%$ & $25.0 \%$ & $50.0 \%$ & $11.2 \%$ & $50.0 \%$ & $39.5 \%$ & 17 \\
\hline & $\begin{array}{l}\text { Middle-high } \\
\text { experimental } \\
\text { income }(30)\end{array}$ & $50.4 \%$ & $46.6 \%$ & $54.7 \%$ & $42.0 \%$ & $52.4 \%$ & $24.0 \%$ & $19.6 \%$ & $41.1 \%$ & $28.4 \%$ & $26.5 \%$ & 11 \\
\hline & $\begin{array}{l}\text { High experimental } \\
\text { income (40) }\end{array}$ & $53.9 \%$ & $42.1 \%$ & $66.1 \%$ & $33.9 \%$ & $60.6 \%$ & $15.3 \%$ & $20.1 \%$ & $65.1 \%$ & $14.7 \%$ & $20.2 \%$ & 16 \\
\hline
\end{tabular}

Source: Original data collected by authors

In the first experiment and the first treatment, the participants with a higher experimental income contributed higher percentage of their income to the Group account 1 (G1). In the second treatment, middle-high and high-income participants increased their contributions to the Group account $(\mathrm{G})$ with high-income participants investing on average up to $75 \%$ of their experimental money to the Group account 1 (G1). In the 
third treatment, the provision point was removed, but a new group account was added. The existence of the new group account resulted in the redistribution of contributions previously contributed to one group account between the two group accounts. This becomes obvious if we compare the average contributions to the private account in the second and third treatments. Low-income and middle-low income participants contributed higher percentage of their experimental income to the Group account 1 (G1) and middle-high and high-income participants directed higher percentage of their income to the group account 2 (G2).

In the second experiment, where the subject were students, all subjects contributed about the same percentage of their income to the Group account 1 (G1), (40\% in the first treatment). In the second treatment, low-income and middle-low income subjects increased their contributions to the Group account 1 (G1), while middle-high and high-income ones reduced their contribution to this account. In the third treatment, similar behavior could be observed as in the previous experiment. The contributions to the private account did not change significantly and the percentage of income contributed in one group account was again redistributed between two group accounts. During the second experiment, private account contributions $(\mathrm{P})$ decreased significantly. In the first treatment, middle-low income participants contributed $60 \%$ of their income to the private account (P), compared to only $11.2 \%$ of their income in the fourth treatment.

In the first experiment, the subjects with middle-high and high income were, on average, more willing to contribute to the Group account 2, thus, they were more willing to contribute to public goods financing if they were members of a large group. However, the data from the second experiment suggest the opposite results. In the second experiment, on average, more those subjects willing to contribute to financing of public goods within a large group were subjects with low and middle-low income.

We use the Wilcoxon test to calculate, how many subjects have changed their behavior during the game, i.e., increased or decreased their contributions and how many subjects did not change their behavior. First, we compare the group account contributions between the first treatment and all other treatments ( $2 t$ vs. $1 t, 3 t$ vs. 1t, $4 t$ vs. $1 t$ ) and then, we compare the third treatment with the second treatment (3t vs. $2 t$ ) and the fourth treatment with the third treatment (4t vs. 3t). 
Table 3: Wilcoxon test - The contributions to the Group account 1

\begin{tabular}{|c|c|c|c|c|c|}
\hline & & $\begin{array}{l}\text { The number of } \\
\text { subjects who } \\
\text { increased their } \\
\text { contributions }\end{array}$ & $\begin{array}{l}\text { The number of } \\
\text { subjects who } \\
\text { decreased their } \\
\text { contributions }\end{array}$ & $\begin{array}{l}\text { The number of } \\
\text { subjects who } \\
\text { contributed the } \\
\text { same amount of } \\
\text { experimental money }\end{array}$ & p- value \\
\hline \multirow[t]{5}{*}{$\begin{array}{l}\text { First } \\
\text { experiment }\end{array}$} & $\begin{array}{l}\text { Group account } 1 \\
\text { (2t vs. } 1 t)\end{array}$ & 11 & 13 & 16 & 0.0581 \\
\hline & $\begin{array}{l}\text { Group account } 1 \\
(3 \mathrm{t} \text { vs. } 1 \mathrm{t})\end{array}$ & 5 & 28 & 7 & 0.0000 \\
\hline & $\begin{array}{l}\text { Group account } 1 \\
\text { (4t vs. } 1 t)\end{array}$ & 6 & 26 & 8 & 0.0000 \\
\hline & $\begin{array}{l}\text { Group account } 1 \\
(3 \mathrm{t} \text { vs. } 2 \mathrm{t})\end{array}$ & 3 & 28 & 9 & 0.0000 \\
\hline & $\begin{array}{l}\text { Group account } 1 \\
\text { (4t vs. } 3 t)\end{array}$ & 13 & 7 & 20 & 0.0209 \\
\hline \multirow[t]{5}{*}{$\begin{array}{l}\text { Second } \\
\text { experiment }\end{array}$} & $\begin{array}{l}\text { Group account } 1 \\
\text { (2t vs. } 1 \mathrm{t})\end{array}$ & 27 & 26 & 7 & 0.0831 \\
\hline & $\begin{array}{l}\text { Group account } 1 \\
(3 \mathrm{t} \text { vs. } 1 \mathrm{t})\end{array}$ & 7 & 44 & 9 & 0.0000 \\
\hline & $\begin{array}{l}\text { Group account } 1 \\
\text { (4t vs. } 1 \mathrm{t})\end{array}$ & 11 & 40 & 9 & 0.0000 \\
\hline & $\begin{array}{l}\text { Group account } 1 \\
(3 \mathrm{t} \text { vs. } 2 \mathrm{t})\end{array}$ & 6 & 42 & 12 & 0.0000 \\
\hline & $\begin{array}{l}\text { Group account } 1 \\
(4 t \text { vs. } 3 t)\end{array}$ & 17 & 20 & 23 & 0.0957 \\
\hline
\end{tabular}

Source: Original data collected by authors

The results of the Wilcoxon test show that a statistically significant proportion of subjects reduced their group account 1 contributions in both experiments. The strategy of reducing contributions to the Group account 1 was chosen by most subjects in the third treatment, when there was a modification, i.e., another group account was added.

To examine how behavior of subjects changed, when a provision point was added, we compared contributions to the Group account 1 in the first and second treatments (2t vs. 1t), contributions to the Group account 1 in the third and fourth treatment (4t vs. 3t) and contributions to the Group account 2 in the third and fourth treatment (4t vs. 3t) (see Table 4). 
Table 4: Wilcoxon test - Effects of the provision point mechanism

\begin{tabular}{|c|c|c|c|c|c|}
\hline & & $\begin{array}{l}\text { The number of } \\
\text { subjects who } \\
\text { increased their } \\
\text { contributions }\end{array}$ & $\begin{array}{l}\text { The number of } \\
\text { subjects who } \\
\text { decreased their } \\
\text { contributions }\end{array}$ & $\begin{array}{l}\text { The number of } \\
\text { subjects who } \\
\text { contributed the } \\
\text { same amount of } \\
\text { experimental money }\end{array}$ & $\mathrm{p}$-value \\
\hline \multirow[t]{3}{*}{$\begin{array}{l}\text { First } \\
\text { experiment }\end{array}$} & $\begin{array}{l}\text { Group account } 1 \\
\text { (2t vs. 1t) }\end{array}$ & 11 & 13 & 16 & 0.0581 \\
\hline & $\begin{array}{l}\text { Group account } 1 \\
(4 t \text { vs. } 3 t)\end{array}$ & 13 & 7 & 20 & 0.0209 \\
\hline & $\begin{array}{l}\text { Group account } 2 \\
(4 \mathrm{t} \text { vs. } 3 \mathrm{t})\end{array}$ & 11 & 10 & 19 & 0.0886 \\
\hline \multirow[t]{3}{*}{$\begin{array}{l}\text { Second } \\
\text { experiment }\end{array}$} & $\begin{array}{l}\text { Group account } 1 \\
\text { (2t vs. } 1 \mathrm{t})\end{array}$ & 27 & 26 & 7 & 0.0831 \\
\hline & $\begin{array}{l}\text { Group account } 1 \\
(4 \mathrm{t} \text { vs. } 3 \mathrm{t})\end{array}$ & 17 & 20 & 23 & 0.0957 \\
\hline & $\begin{array}{l}\text { Group account } 2 \\
\text { (4t vs. } 3 t)\end{array}$ & 26 & 10 & 24 & 0.0027 \\
\hline
\end{tabular}

Source: Original data collected by authors

In the first experiment and the second treatment compared to the first treatment, most subjects decided not to change their strategy. Thus, the modification did not have a statistically significant impact on individual behavior. We can conclude the same when we compare the third and the fourth treatment. Nevertheless, in this experiment, more than the minimum amount of contributions (provision point) was collected in the second treatment by six small groups out of the total of eight groups, and in the fourth treatment, three out of four large groups contributed more than the value of the provision point.

In the second experiment and the second treatment, even though most subjects increased their group account contributions, this change was not statistically significant. A statistically significant change in contributions to the Group account 2 was observed in the fourth treatment. Thus, the provision point had a statistically significant effect on the increase of contributions to the Group account 2. In this experiment, nine groups out of total of twelve groups contributed more than the provision point value in the second treatment and in the fourth treatment, the provision point value was overcome by five large groups out of total of six large groups.

To provide a more comprehensive insight on the individual decisions of participants on the split of their income between the public and private accounts, we also present the results of Wilcoxon test for the private account. Again, we compare each experiment separately. First, we compare all treatments with the first treatment ( $2 t$ vs. $1 \mathrm{t}, 3 \mathrm{t}$ vs. $1 \mathrm{t}, 4 \mathrm{t}$ vs. $1 \mathrm{t}$ ), then, the remaining treatments are compared with each other (3t vs. $2 t$ and $4 t$ vs. $3 t$ ). 
Table 5: Wilcoxon test - The contributions to the private account

\begin{tabular}{|c|c|c|c|c|c|}
\hline & & $\begin{array}{l}\text { The number of } \\
\text { subjects who } \\
\text { increased their } \\
\text { contributions }\end{array}$ & $\begin{array}{l}\text { The number of } \\
\text { subjects who } \\
\text { decreased their } \\
\text { contributions }\end{array}$ & $\begin{array}{l}\text { The number of } \\
\text { subjects who } \\
\text { contributed the } \\
\text { same amount of } \\
\text { experimental money }\end{array}$ & $\mathrm{p}$ - value \\
\hline \multirow[t]{5}{*}{$\begin{array}{l}\text { First } \\
\text { experiment }\end{array}$} & $\begin{array}{l}\text { Private account } \\
(2 \mathrm{t} \text { vs. } 1 \mathrm{t})\end{array}$ & 13 & 11 & 16 & 0.0596 \\
\hline & $\begin{array}{l}\text { Private account } \\
(3 \mathrm{t} \text { vs. } 1 \mathrm{t})\end{array}$ & 15 & 16 & 9 & 0.0818 \\
\hline & $\begin{array}{l}\text { Private account } \\
\text { (4t vs. } 1 \mathrm{t})\end{array}$ & 18 & 14 & 8 & 0.0351 \\
\hline & $\begin{array}{l}\text { Private account } \\
(3 \mathrm{t} \text { vs. } 2 \mathrm{t})\end{array}$ & 11 & 13 & 16 & 0.0836 \\
\hline & $\begin{array}{l}\text { Private account } \\
(4 \mathrm{t} \text { vs. } 3 \mathrm{t})\end{array}$ & 7 & 15 & 18 & 0.0224 \\
\hline \multirow[t]{5}{*}{$\begin{array}{l}\text { Second } \\
\text { experiment }\end{array}$} & $\begin{array}{l}\text { Private account } \\
(2 \mathrm{t} \text { vs. } 1 \mathrm{t})\end{array}$ & 28 & 25 & 7 & 0.0459 \\
\hline & $\begin{array}{l}\text { Private account } \\
(3 \mathrm{t} \text { vs. } 1 \mathrm{t})\end{array}$ & 26 & 27 & 7 & 0.0960 \\
\hline & $\begin{array}{l}\text { Private account } \\
(4 \mathrm{t} \text { vs. } 1 \mathrm{t})\end{array}$ & 24 & 28 & 8 & 0.06354 \\
\hline & $\begin{array}{l}\text { Private account } \\
(3 \mathrm{t} \text { vs. } 2 \mathrm{t})\end{array}$ & 14 & 31 & 15 & 0.0677 \\
\hline & $\begin{array}{l}\text { Private account } \\
(4 \mathrm{t} \text { vs. } 3 \mathrm{t})\end{array}$ & 17 & 25 & 18 & 0.1653 \\
\hline
\end{tabular}

Source: Original data collected by authors

Based on the data in the Table 5, no treatment modification in both experiments had a statistically significant effect on contributions to the private account. In the first experiment, the most significant increase in private account contributions was in the fourth treatment when compared with the first treatment. In the second experiment, most subjects increased their private account contributions in the second treatment when compared with the first treatment.

Now, we use a multiple linear regression model with the dependent variable being contributions to the Group account 1 . Independent variables are dummy variables for each treatment, experimental income, age, gender and university education. 
Table 6: The effect of treatment modifications, experimental income, education and gender on contributions to the group account

\begin{tabular}{|c|c|c|c|}
\hline Variables & First experiment & Second experiment & First + second experiment \\
\hline Constant & $\begin{array}{c}48.855 * * * \\
(7,058)\end{array}$ & $\begin{array}{c}74.651 \text { *** } \\
(8,555)\end{array}$ & $\begin{array}{c}61.146^{* * * *} \\
(5,631)\end{array}$ \\
\hline Second treatment & $\begin{array}{c}-5.729 * * \\
(5,572) \\
\end{array}$ & $\begin{array}{c}-7.583 * * \\
(5,941) \\
\end{array}$ & $\begin{array}{c}-6.754 * * \\
(4,267) \\
\end{array}$ \\
\hline Third treatment & $\begin{array}{c}-25.791 * * * \\
(5,572)\end{array}$ & $\begin{array}{c}-19.069 * * * \\
(5,941)\end{array}$ & $\begin{array}{c}-21.679 * * * \\
(4,267)\end{array}$ \\
\hline Fourth treatment & $\begin{array}{c}-23.208 * * * \\
(5,572)\end{array}$ & $\begin{array}{c}-2.403^{* * * *} \\
(5,941)\end{array}$ & $\begin{array}{c}-10.638 * * * \\
(4,627)\end{array}$ \\
\hline Experimental income & $\begin{array}{c}-0.284 * * \\
(0,186)\end{array}$ & $\begin{array}{c}-1.041 * * * \\
(0,222)\end{array}$ & $\begin{array}{c}-0.617 * * * \\
(0,139)\end{array}$ \\
\hline Woman & $\begin{array}{l}5.937 * \\
(3,971) \\
\end{array}$ & $\begin{array}{l}-2.206 * \\
(4,316) \\
\end{array}$ & $\begin{array}{l}1.808^{*} \\
(3,061) \\
\end{array}$ \\
\hline Age (16-30) & $\begin{array}{l}-0.339 * \\
(4,561)\end{array}$ & - & $\begin{array}{l}-0.339 * \\
(0,941)\end{array}$ \\
\hline University education & $\begin{array}{l}2.329^{*} \\
(4,833)\end{array}$ & - & $\begin{array}{l}-1.992 * \\
(3,311)\end{array}$ \\
\hline $\mathrm{R}^{2}$ & 0.1956 & 0.133 & 0.1956 \\
\hline
\end{tabular}

Source: Original data collected by authors

Note: Standard deviations are in the parentheses

$*, * *, * * *$ denote to significant at 10,5 and 1 percent levels

All modifications introduced in the experiment had a statistically significant effect on contributions to the Group account 1. In both experiments, there could be observed a decrease in contributions to the Group account 1. It can be possibly explained by the fact that the experiment was run online, which could be reflected in the willingness to behave pro-socially and to contribute to the group accounts. Even in the experimental laboratories, the experiments are performed anonymously, but the participants can see potential members of their groups, which is impossible in online experiments. The most significant decrease in contributions was observed in the third treatment, when another group account was added. The experimental income is statistically significant at 5 percent level in the first experiment and at 1 percent level in the second experiment. However, individuals with smaller income contributed more to the public goods. The age of the subjects had a negative impact on public goods contributions (at 10 percent level of significance). Subjects with university education were more willing to contribute to public goods (at 10 percent level of significance). In case of gender. We did not find statistically significant differences between contributions of men and women. 


\section{Conclusions}

The results of our analysis suggest that in both experiments, the subjects were willing to contribute to the group accounts, which were used as a proxy for contributions to public goods. This willingness persisted regardless of whether they were members of a small or a large group. Most subjects decided to contribute at least small fraction of their income to both group accounts. The results also show that some subjects were more willing to contribute to the financing of public goods if they were a member of a large group. A statistically significant factor affecting individual contributions was individual income. Low-income participants were even more willing to participate in the voluntary financing of public goods. The findings of our research point to the limited validity of the rationality of individual actions. We found that even though a free rider problem cannot be completely resolved using this mechanism, its impact is probably more limited than predicted by standard economics.

A thorough analysis of individual contributions in both experiments shows that subjects were voluntarily willing to contribute their experimental money to the Group account 2. However, there were several specificities. In the first experiment, low-income participants were more willing to contribute to the Group account 2, while in the second experiment, the middle-high and high-income participants contributed more to the Group account 2. The results of the first experiment showed, that the group account contributions in the third and fourth treatments corresponded to the contributions to the Group account 1 in earlier treatments, thus, private account contributions remained unchanged. However, in the second experiment, subjects in the third and fourth treatments were willing to contribute larger fraction of their income to both group accounts compared to earlier treatment. Thus, there was larger decrease in their private account contribution esp. in the last (fourth) treatment of the experiment.

Nowadays, none of the alternative mechanisms of providing public goods is universally accepted, so further theoretical and applied research is needed to formulate alternative methods to financing and provision of public goods. Behavioral economics studying human decision-making in simulated or also real-life settings opens new opportunities in this direction. The success of the use of alternative mechanisms to finance public goods could increase competition in the provision of public goods and, thus, contribute to improving their quality. At the current stage it is not possible to make a clear-cut distinction between those goods, which should be financed only through the public domain and those, which should be financed by the private sector. Further research can focus on the appropriate mix of both alternatives for their enhanced provision in higher quality. 


\section{Acknowledgement}

The paper was supported by the Grant Agency VEGA under its project No. 1/0239/19 - "Implications of Behavioral Economics for Streamlining the Functioning of Current Economies" and by the Grant Agency APPV under its project No. 18-0435 - Behavioral Interventions in Local Government: Increasing the Efficiency of Local Public Policies.

\section{REFERENCES}

Andreoni, J. (1988). Why free ride? Strategies and Learning in Public Goods Experiments. Journal of Public Economics, 37 (3), 291-304, doi: 10.1016/0047-2727(88)90043-6.

Bagnoli, M., Lipman, B. L. (1992). Private provision of public goods can be efficient. Public Choice, 74 (1), 59-78, doi: 10.1007/BF00175211

Bergstrom, T., Blume, L., \& Varian, H. (1986). On the private provision of public goods. Journal of Public Economics, 29 (1), 25-49, doi:10.1016/0047-2727(86)90024-1

Buckley, E., \& Croson, R. (2006). Income and wealth heterogeneity in the voluntary provision of linear public goods. Journal of Public Economics. 90 (1), 935-955, doi: 10.1016/j.jpubeco.2005.06.002

Cornes, R., Sandler, T. (1984). Easy Riders, Joint Production, and Public Goods. The Economics journal, 94 (375), 580-598, doi: 10.2307/2232704

Cornes, R., Sandler, T. (1985). The Simple Analytics of Pure Public Good Provision. Economica, 52 (205), 103-116, doi: 10.2307/2553994

Croson, R., Fatas, E., \& Neugebauer, T. (2005). Reciprocity, matching and conditional cooperation in two public goods games. Economics Letters, 87 (1), 95-101, doi: 10.1016/j.econlet.2004.10.007

Hofmeyr, A., Burns, J., \& Visser, M. (2007). Income inequality, reciprocity and public good provision: an experimental analysis. South African Journal of Economics, 75(3), 508-520, doi: 10.1111/j.1813-6982.2007.00127.x

Isaac, R. M., Walker, J.M., \& Thomas, S.H. (1984). Divergent evidence on free riding: An experimental examination of possible explanations. Public Choice, 43(2), 113-149, doi: 10.1007/BF00140829

Isaac, R., McCue, K., \& Plott, Ch. (1985). Public goods provision in an experimental environment. Journal of Public Economics, 26 (1), 51 - 74, doi: 10.1016/0047-2727(85)90038-6

Kurzban, R., McCabe, K., \& Smith, V. (2001). Incremental Commitment and Reciprocity in Real-Time Public goods Game. Personality and Social Psychology Bulletin, 27 (12), 1662- 1673. doi: 10.1177/01461672012712009

Marwell, G., \& Ames, R.E. (1979). Experiments on the Provision of Public Goods. I. Resources, Interest, Group Size, and the Free-Rider Problem. American Journal of Sociology. 84(6),13351360, doi: $10.1086 / 226937$

Marwell, G., \& Ames, R.E. (1980). Experiments on the Provision of Public Goods. II. Provision Points, Stakes, Experience, and the Free-Rider Problem. American Journal of Sociology. 85 (4), 926-937, doi: 10.1086/227094

McBride, M. (2004). Discrete public goods under threshold uncertainty. Journal of Public Economics, 90 (6-7), doi: 10.1016/j.jpubeco.2005.09.012

Olson, M. (1965). The Logic of Collective Action: Public goods and the theory of groups. Cambridge: Harvard University Press. ISBN 978-0674537514

Robeldo, J. R. Essays on the private provision of public goods. Aachen: Shaker. 2000. ISBN 9783826559969. 